\title{
Research on the influences of high salt water on $\mathrm{CaCO}_{3}$ dissociation Xiaoyu Weng ${ }^{1, a}$ \\ ${ }^{1}$ School of North China Electric Power University(Baoding), Baoding, 071003, China;
}

Keywords: Saline water, Flue gas desulfurization, $\mathrm{CaCO} 3$ dissociation.

\begin{abstract}
For the consideration of wastewater zero discharge, many coal-fired power plants reuse the reverse osmosis concentrated water and chemical drainage in the desulfurization system ,but studies of influence to the $\mathrm{CaCO} 3$ dissociation by highly concentrated saline wastewater are rare. This paper analyzes negative influences of all kinds of ions when seperately exist in absorption tower, discussed the negative effect mechanism of highly concentrated saline wastewater on the $\mathrm{CaCO} 3$ dissociation.This study provides the reference for engineer practice when predicting the $\mathrm{CaCO} 3$ dissociation with all kinds of ions in.
\end{abstract}

\section{Introduction}

From the view point of sustainable development ,the depth of water is one of the best measures for coal-fired power plants.Thus saline wastewater used for desulfurization system back, and then taking the desulfurization wastewater to a unified treatment is feasible.But little is known about the possible impact of[1].So we analyzes the existing in the salt water of various ion specific effects on the desulfurization system and clear the mechanism of action of key, which has far-reaching significance.

\section{Mechanism of action}

Various ions have different impact on the $\mathrm{CaCO}_{3}$ dissociation by affecting the ionic strength, the surface tension of the limestone、 he solubility of sulfate and the changes of chemical equilibrium. For example, the increase of concentration of $\mathrm{C}^{\mathrm{l}}$ - will restrain the spread of $\mathrm{H}+$, decreasing the $\mathrm{CaCO}_{3}$ particle interface layer on the surface of $\mathrm{H}+$ concentration and reducing the limestone dissolution rate. The increase of concentration of $\mathrm{SO}_{3}{ }^{2}-$ and $\mathrm{Mg} 2+$ will improve the circulation of serum alkalinity, so as to reduce the liquid phase mass transfer resistance, which is more conducive to the limestone dissolution[2-3].

\section{The influences of various ions}

\subsection{The influence of $\mathrm{Cl}^{-}$}

In slurry of WFGD system , chloride mostly exists in the form of $\mathrm{CaC}_{1}^{2}$. With the increase of concentration of $\mathrm{C}_{1^{-}}$and will affect the decomposition rate of $\mathrm{CaCO}_{3}$,changing the $\mathrm{pH}$ value, reduceing the removal rate of $\mathrm{SO}_{2}$. Ukawa [2] thinks when solution containing $\mathrm{C}_{l^{-}}$, will increase the ionic strength of solution, stopping the spread of $\mathrm{H}+$.Decrease the concentration of $\mathrm{H}+$ on the surface of the $\mathrm{CaCO}_{3}$ particle interface layer, which increases the liquid phase mass transfer resistance, reducing the limestone dissolution rate.

\subsection{The influence of $\mathrm{SO}_{3}{ }^{2-}$}

$\mathrm{SO}_{3}{ }^{2-}$ will inhibits the solution of $\mathrm{CaCO}_{3}$. Happens when high relative saturation sulfite sulphite serious inhibition. Phenomenon of sulfite serious inhibition is the running $\mathrm{pH}$ falling, which running $\mathrm{pH}$ is out of control. The utilization rate of limestone cannot maintain the use ratio we want even in the setting $\mathrm{pH}$ value,and the limestone concentration in the slurry will increase ${ }^{[3]}$.

\subsection{The infulence of $\mathrm{SO}_{4}{ }^{2-}$}

The existence of $\mathrm{SO}_{4}{ }^{2-}$ can promote the dissolution of the limestone.Because $\mathrm{SO}_{4}{ }^{2-}$ and $\mathrm{H}^{+}$form $\mathrm{HSO}_{4}{ }^{-}$, the mass transfer coefficient will increase and the limestone dissolution rate can magnify, 
thus improve the desulphurization efficiency ${ }^{[4]} \cdot \mathrm{Ca}^{2+}$ and $\mathrm{SO}_{4}{ }^{2-}$ form $\mathrm{CaSO}_{4}$ consuming more $\mathrm{Ca}^{2+}$ in the solution, which make the rate of positive reaction increase

\subsection{The influence of $\mathrm{Al}^{3+}$ or $\mathrm{F}^{-}$}

When joining $\mathrm{Al}^{3+}$ and $\mathrm{F}^{-}$aloneor in the limestone solution , for the influence of limestone dissolution is relatively minor. And after adding $\mathrm{Al}^{3+}$ or $\mathrm{F}^{-}$at the same time, the limestone dissolution rate will decline because of the formation of $\mathrm{AlF}_{\mathrm{X}}$. That cover on the surface of limestone, hindering the mass transfer factor between the liquid subject and the limestone particles, which seriously inhibit the dissolution of the limestone ${ }^{[5]}$.

\subsection{The influence of $\mathrm{Na}^{+}$}

$\mathrm{Na}^{+}$can reduce the liquid mass transfer resistance and the resistance of the dissolution of limestone, effectively increasing the mass transfer coefficient and enhancement factor,making the limestone dissolve quickly ${ }^{[6]}$.

\subsection{The influence of $\mathrm{Ca}^{2+}$}

In salt water The presence of $\mathrm{Ca}^{2+}$ is bound to affect the limestone dissolution.For the same ion effect, the greater the concentration of $\mathrm{Ca}^{2+}$ in the salty water, the stronger the inhibition of limestone, which make limestone solubility decrease ${ }^{[7]}$.

\subsection{The infulence of $\mathbf{M g}^{2+}$}

The existence of $\mathrm{Mg}^{2+}$ can work wonderfully for limestone slurry desulfurization by a collaborative and promoting influence. Because the $\mathrm{MgSO}_{4}$ in water solubility is higher than $\mathrm{CaSO}_{4}$, leading to an elevated serum concentrations of $\mathrm{SO}_{4}{ }^{2-}$, making it easier to form precipitation with $\mathrm{Ca}^{2+[4]}$.

\section{Conclusion}

When high concentration salty wastewater use back to desulfurization system, $\mathrm{Cl}^{-}, \mathrm{F}^{-}, \mathrm{SO}_{3}{ }^{2-}, \mathrm{Al}^{3+}$ and $\mathrm{Ca}^{2+}$ shall be reduced to reduce the effects of the dissolution of the limestone. We can keep appropriate concentration of $\mathrm{Na}^{+}, \mathrm{Mg}^{2+}$ and $\mathrm{SO}_{4}{ }^{2-}$ existing in wastewater at the same time,and three kinds of ions can promote the dissolution of the limestone layer in different degrees.

\section{References}

[1]Xiao Ting,Xia Kefei.Study and practice of zero discharge technology of efficient form thermal power plant.Environment and Ecology in the Three Gorges, Vol.33(2011)No.06,p.23-26.2011.

[2]Gage C L,Rochelle G T.Limestone dissolution in flue gas scrubbing effect of sulfite.Journal of Air Waste management Association,Vol.42(1992)No.07,p.926-935.

[3]Huo Wang:Mechanism research on the absorption、 oxidation and crytallization in the process of limestone-Gypsum Wet Flue Gas Desulfurization (Ph.D,Zhejiang University,China,2009).

[4]Zhou Zhixiang ,Duan Jianzhong,Xue Jianming.Manual coal-fired power plant wet flue gas desulfurization technology.China Electric Power Press,2006,p.24-245.

[5]Ma Shuangchen,Han Gang.The model of limestone dissolution and its application in wet flue gas desulfurization.Electric Power Technology and Environmental Protection,Vol.29(2013)No.02,p.7-9.

[6]Dong Liyan,Cheng Kaihao,Liu Lei.Study on the mechanism of Wet-FGD synergist.Guangdong Chemical Industry,Vol.41(2014)No.18,p. 133-134.

[7]Gu Yinna.Study on reactivity of the limestone in wet flue gas desulfurization(master's degree,Nanjing University of Science and Technology,China,2006). 